\title{
РЕЗУЛЬТАТИ ЕМПІРИЧНОГО ДОСЛІДЖЕННЯ КОМПЕТЕНТНОСТІ ДІЛЬНИЧНИХ ІНСПЕКТОРІВ ПРИКОРДОННОЇ СЛУЖБИ У ПРОФЕСІЙНОМУ СПІЛКУВАННІ
}

УДК: $159.9: 316.6$

\section{Преснякова Людмила Валерї̈вна \\ Стариий офіцер відділу очінки інформації ін- формаційно-аналітичного управління Адмініст- рачії Державної прикордонної служби Украї- ни, м. Київ (Україна)}

\begin{abstract}
Анотація. У статті наведено результати емпіричного дослідження компетентності дільничних інспекторів прикордонної служби у професійному спілкуванні. Встановлено, щуо інспектори мають недостатній рівень знань (когнітивний компонент) та навичок (поведінковий компонент) професійного спілкування, нерозвинені професійно важливі особистісні якості (особистісний компонент), щзо негативно впливає на ефективність їх професійної діяльності. Виявлено високий рівень негативних комунікативних установок, агресивності та ворожості у спілкуванні, нерозвинена комунікативна толерантність, емпатійність та рефлексивність, неконструктивні стратегії поведінки в конфлікті. Зроблено висновок, щя всі компоненти компетентності дільничних інспекторів прикордонної служби у професійному спілкуванні сформовані на рівні нижчому за середній і потребують подальшого розвитку.
\end{abstract}

Ключові слова: професійне спілкування, знання, вміння, навички, особистісні якості, компетентність у спілкуванні, комунікативна компетентність, периеетивна компетентність, інтерактивна компетентність.

\section{Постановка проблеми у загальному} вигляді та її зв'язок із важливими науковими чи практичними завданнями. Дослідження шляхів розвитку компетентності у спілкуванні дільничних інспекторів прикордонної служби ускладняється відсутністю загальноприйнятих визначень родових понять «спілкування», «компетентність», «компетенція» та видових понять «професійне спілкування», «ділове спілкування», «компетентність у професійному спілкуванні». Зміст та психологічні особливості професійного спілкування дільничних інспекторів прикордонної служби (ДІПС) визначаються змістом їх професійної діяльності. Рівень компетентності ДІПС у професійному спілкуванні визначається глибиною наявних у них знань, розвиненістю вмінь, навичок та 
особистісних якостей, що забезпечують точність обміну інформацією, адекватність взаємосприйняття та ефективність взаємодії 3 широким колом осіб спрямованої на забезпечення надійної охорони державного кордону в зоні відповідальності інспектора. Водночас, рівень компетентності ДІПС у професійному спілкуванні безпосередньо визначає рівень професійної компетентності ДІПС як правоохоронця. Зазначене робить емпіричне дослідження компетентності ДІПС у професійному спілкуванні важливим науково-практичним завданням, розв'язання якого сприятиме пошуку науково обгрунтованих шляхів підвищення рівня професійної компетентності цієї категорії охоронців кордону.

\section{Аналіз останніх досліджень i} публікацій, в яких започатковано вирішення даної проблеми та на які опирається автор.

Професійне спілкування відіграє визначальну роль в діяльності з охорони державного кордону. Особливості цього виду правоохоронної діяльності визначають характер професійного спілкування прикордонників, зумовлюють його специфічність [1, с. 106]. Дослідник психологічних особливостей службоводілового спілкування керівного складу органів та підрозділів прикордонного відомства В. О. Назаренко відзначає, що основними психологічними умовами розвитку компетентності керівника у професійному спілкуванні $є$ усвідомлення взаємозв'язку між рівнем особис- тої комунікативної компетентності та ефективністю службово-ділової взаємодії, самостійне визначення цілей, змісту та результатів навчання, співвідношення теорії $з$ наявними особистими проблемами у службово-діловій взаємодії, поєднання розв'язання службоводілових ситуацій з тренінгом сенситивності, активна взаємодія учасників розв'язання службово-ділових ситуацій, одночасне удосконалення продуктивної та репродуктивної складових комунікативної компетентності, які впливають на її розвиток у керівників [2, с. 1314].

В цілому проблемі професійного спілкування прикордонників присвячено певну кількість наукових розробок, але практично всі вони стосуються підготовки до професійного спілкування офіцерів-прикордонників, водночас дослідження психологічних особливостей та шляхів розвитку компетентності у професійному спілкуванні інших

Метою статті є викладення і аналіз результатів емпіричного дослідження компетентності ДІПС у професійному спілкуванні.

\section{Виклад основного матеріалу дослі-} дження 3 повним обгрунтуванням отриманих наукових результатів. Емпіричне дослідження компетентності ДІПС побудовано на основі авторської моделі, яка передбачає, що компетентність у професійному спілкуванні ДІПС визначається комунікативною, перцептивною та інтерактивною компетентностями, кожна $з$ яких містить когнітивну, особистісну 
та поведінкову складові. Дослідження когнітивного компоненту складових компетентності ДІПС у професійному спілкуванні було проведено за допомогою авторського опитувальника. Аналіз результатів свідчить про недостатній рівень знання інспекторами як загальних характеристик професійної діяльності, так i психологічних особливостей усіх складових професійного спілкування. Краще ДІПС орієнтуються у загальних характеристиках професійного спілкування - 80,31\% опитаних продемонстрували високий i середній рівень знань. Найгірше ДІПС знають психологічні особливості перцептивної складової професійного спілкування - 62,99\% опитаних продемонстрували низький рівень знань. Отримані результати можна пояснити тим, що лише незначна кількість ДІПС має вищу освіту, при цьому призначення на посаду ДІПС не передбачає проходження спеціальної професійної підготовки. Тому, обираючи правильні відповіді на запитання опитувальника, ДІПС, скоріше орієнтувалися не стільки на свої знання, скільки на інтерпретацію власного досвіду спілкування, приймали рішення за аналогією, а в деяких випадках робили свій вибір навмання. Запитання для блоку опитувальника на знання особливостей перцептивної складової професійного спілкування вимагали чіткого знання ефектів та механізмів міжособистісної перцепції, яких у ДІПС не було, саме це і визначило значну кількість невірних відповідей. Рівень знань особливостей комунікативної та інтера- ктивної складової професійного спілкування також незадовільний, лише 55,12\% та 52,76\% опитаних показали високий та середній рівень знань.

Особистісний компонент комунікативної компетентності ДІПС у професійному спілкуванні було досліджено з використанням методик діагностики комунікативної установки (В. В. Бойко), діагностики показників i форм агресії (Баса-Даркі), діагностики комунікативних та організаторських схильностей (КОС-2). Отримані дані свідчать про досить високий рівень сформованості у ДІПС негативних комунікативних установок. Так, у значної кількості опитаних діагностовано високий і середній рівень сформованості установок на «приховану жорстокість у відношенні до інших людей» та «відкрита жорстокість у відношенні до інших людей»- 74,02\% та $61,42 \%$ відповідно. За умови високих рівнів сформованості зазначених установок, інспектор робить швидкі, різкі і однозначні висновки про партнера по професійному спілкуванню, а у разі кратного спілкування ці висновки і манера спілкування, як правило, вже не змінюються.

Значна кількість осіб з високим та середнім рівнем розвиненості комунікативної установки на «обумовлений негативізм у судженнях про інших людей» $(81,1 \%)$ свідчить про стійку готовність ДІПС до упереджених, у багатьох випадках, негативних висновків про громадян, які не залежать від конкретного змі- 
сту інформації, яку вони від них отримують. У значної кількості ДІПС сформовані високий та середній рівні установки на «схильність до необгрунтованих узагальнень негативних фактів у сфері взаємостосунків 3 іншими людьми» (82,68\%), що може свідчити про певні професійно деформаційні зміни особистості інспекторів, які пов'язані з процесом адаптації правоохоронців до умов професійної діяльності, що динамічно змінюються останні кілька років і характеризується упередженим негативізмом у ставленні до прикордонників з боку певної частини суспільства.

Для уточнення змісту комунікативних установок, у учасників дослідження було діагностовано рівень сформованості загальної комунікативної толерантності. Отримані результати дозволяють зробити висновок, про значну кількість ДІПС у яких діагностовано низький рівень загальної комунікативної толерантності, тобто високі показники за всіма запропонованими характеристиками - 23,62\%. Зазначене свідчить, що у багатьох випадках ДІПС обмежують коло свого професійного спілкування лише тими, кого вважають приємними співрозмовниками, відчувають труднощі у встановленні і підтриманні контактів, демонструють у спілкуванні конфліктність, прискіпливість, грубість, роздратування, зневагу до партнера, що створює комунікативні бар'єри, знижує якість обміну інформацією і продуктивність професійної діяльності.

Результати діагностування рівня сфор- мованості агресивності та ворожості у професійному спілкуванні викликають увагу до значної кількості інспекторів, які продемонстрували високий рівень підозрілості (33,07\%); непрямої агресії $(25,98 \%)$; роздратування (22,83\%); вербальної агресії (21,26\%). Так, прояви підозрілості свідчать про схильність ДІПС до недовіри та обережного ставлення до людей, які формуються під впливом переконання у тому, що оточуючі мають намір заподіяти шкоду. Проявами непрямої агресії у професійному спілкуванні ДІПС можуть бути ненаправлені, неврегульовані, вибухи люті. Роздратування у професійному спілкування ДІПС може проявлятися через готовність до запальності, різкості і брутальності за щонайменшого збудження. Проявами вербальної агресії у професійному спілкуванні ДІПС є вираження негативних почуттів як формально (сварка, крик), так і через зміст словесних звертань до партнерів зі спілкування (погроза, прокляття, лайка).

Стосовно інших проявів агресивності та ворожості у професійному спілкуванні ДІПС слід відзначити відносно невелику кількість ДІПС, які готові демонструвати фізичну агресію (18,9\%), яка проявляється у готовності застосувати заходи фізичного впливу до партнера зі спілкування. Лише 14,96\% опитаних ДІПС схильні до негативізму - опозиційної форми поведінки, що спрямована проти авторитету та керівництва, яка може наростати від пасивного опору до активних дій проти 
вимог, правил, законів. Образливість ДІПС $(14,18 \%)$ проявляється через почуття заздрості і ненависті до оточуючих, які обумовлені, в свою чергу, почуттям гніву, невдоволення кимось конкретно або всім світом в цілому за заподіяні дійсні або уявні страждання. Особливості переживання почуття провини $(10,24 \%)$ визначаються негативним ставленням до себе, своїх дій відносно оточуючих, які виникають через можливе переконання інспектора в тому, що він є поганою людиною, наносить шкоду, діє злобно або безсовісно.

Результати діагностування рівня сформованості комунікативних та організаційних схильностей свідчать, що у значної кількості ДІПС вони розвинені лише на середньому та низькому рівні $(80,31 \%$ та $83,46 \%$ відповідно). Інспектори ДІПС, з низьким рівнем сформованості комунікативних та організаційних якостей не прагнуть до спілкування, скуто почувають себе серед незнайомих та малознайомих людей, обмежують свої знайомства, відчувають труднощі у встановленні контактів 3 людьми й у виступі перед аудиторією, погано орієнтуються у незнайомій ситуації, не відстоюють свою думку, важко переживають образи. У багатьох питаннях уникають самостійних рішень та проявів ініціативи. Інспектори з середнім рівнем розвиненості зазначених якостей прагнуть до контактів із людьми, не обмежують коло своїх знайомств, відстоюють свою думку, планують свою ро- боту, проте роблять це не завжди і потребують подальших зусиль 3 розвитку комунікативних і організаторських схильностей.

Особистісний компонент перцептивної компетентності ДІПС у професійному спілкуванні було досліджено 3 використанням методик діагностики рівня емпатійних здібностей (В. В. Бойко), діагностики рівня розвитку рефлексивності (Карпов А. В.), діагностики мотиваційних орієнтацій у міжособистісних комунікаціях (I. Д. Ладанов, В. А. Уразаева). Аналіз отриманих результатів свідчить, що 82,68\% учасників дослідження мають середній та низький рівні розвитку раціонального каналу емпатії. Це дає можливість стверджувати про недостатню здатність неупереджено виявляти особливості партнера по взаємодії за допомогою уваги, сприйняття та мислення, визначати сутність іншої людини - іiі стан, проблеми, поведінку, що ускладнює професійне спілкування ДІПС. Правоохоронці з нерозвиненим раціональним каналом емпатії не завжди відчувають інтерес до іншої людини, здатні емоційно й інтуїтивно іiі розуміти. Відповідно, такі ДІПС вважають, що інші особи також не відчувають інтересу до них, що зменшує ефективність виконуваних ними завдань.

Дещо краще в учасників дослідження розвинений емоційний канал емпатії $22,05 \%$ мають високий рівень, 56,69\% - середній. ДІПС $з$ високим рівнем розвиненості цього каналу емпатії мають здатність співпе- 
реживати та співчувати. Їх емоційна чуйність стає засобом «входження» в енергетичне поле партнера, дозволяє зрозуміти його внутрішній світ, прогнозувати його поведінку й ефективно впливати на неї.

Найбільш розвиненим в учасників дослідження виявився інтуїтивний канал емпатії. Високий і середній рівні розвиненості цього каналу виявлено у 15,75\% та 65,35\% учасників дослідження відповідно. Такі ДІПС здатні розуміти поведінку партнерів і діяти в умовах браку об'єктивної інформації про них, спираючись на досвід, що зберігається в підсвідомості. Відомості про партнерів формуються на рівні інтуїції, яка менше залежить від стереотипів, ніж осмислене розуміння партнерів. У $33,86 \%$ ДІПС виявлено схильність до уникання особистих контактів, знижену цікавість до іншої особистості, спокійне ставлення до переживань і проблем оточуючих. Це різко обмежує діапазон емоційної чуйності і емпатійного сприйняття.

Значна кількість учасників дослідження $(85,04 \%)$ продемонстрували низьку здатність до емпатії, відчувають труднощі зі створенням у спілкуванні атмосфери відкритості, довіри, задушевності. Можна стверджувати, що 37,80\% ДІПС у багатьох випадках своїми діями перешкоджають словесно-емоційному обміну, створюючи атмосферу напруження, неприродності, підозрілості. У 26,77\% ДІПС діагностовано низький рівень розвитку ідентифікації - ще однієї неодмінної умови успіш- ної емпатії. Вони відчувають труднощі у розумінні іншого на основі співпереживань, постановки себе на місце партнера, рухливості та гнучкості емоцій, здатності до наслідування. Аналізуючи загальну сумарну оцінку рівня емпатії ДІПС, слід відзначити, що лише 18,11\% 3 них мають високий рівень емпатії, а значна кількість правоохоронців (27,56\%) потребують додаткових психологічних заходів 3 iii розвитку.

Результати діагностування рівня розвитку рефлексивності свідчать, що $81,89 \%$ респондентів мають середній та низький рівень рефлексивності. Низький рівень рефлексивності призводить до зниження ефективності професійного спілкування. Через недостатню розвиненість рефлексивності ДІПС не усвідомлює повною мірою, як він сприймається партнером по спілкуванню, не завжди вірно розуміє співрозмовника, що також створює проблеми у спілкуванні. Водночас, ДІПС з високим рівнем рефлексивності (18,11\%) здатні до ефективної взаємодії з партнером у процесі вироблення рішень, розв'язання проблем організації і координації спільної діяльності, розподілу обов'язків, контролю і оцінки спільних дій групи та власних дій кожного 3 партнерів. На думку дослідників проблеми рефлексії, однією з основних причин її недостатньої розвиненості $\epsilon$ низький загальноосвітній рівень [6].

Результати діагностування мотиваційних орієнтацій у міжособистісних комунікаці- 
ях свідчать про досить високий рівень розвитку якостей ДІПС. Так, за кожним зі шкальних показників високий та середній рівні розвитку показало більше половини ДІПС: 60,63\% - за шкалою орієнтація на партнера, 67,72\% - за шкалою орієнтація на адекватність сприйняття і розуміння партнера, 73,23\% за шкалою на досягнення компромісу. В цілому, у 69,36\% опитаних мотиваційні орієнтації у міжособистісних комунікаціях розвинені досить гармонійно.

Особистісний компонент інтерактивної компетентності ДІПС у професійному спілкуванні досліджувався за допомогою тесту «Діагностика лідерських здібностей» (Є. Жариков, Є. Крушельницький), опитувальника К. Томаса «Визначення способів врегулювання конфліктів», методики діагностики спрямованості особистості Б. Басса (опитувальник Смекала-Кучери).

У нашому дослідженні лідерство розглядається як тип професійної взаємодії, який грунтується на здатності ДІПС до більш ефективного для кожної окремої ситуації поєднання різних джерел впливу і спрямований на спонукання партнерів зі спілкування до розв'язання проблем і завдань охорони державного кордону у зоні відповідальності. 3 одного боку, 71,65\% ДІПС показали високий та середній рівень розвиненості лідерських здібностей, а $з$ іншого - майже третина ДІПС не мають лідерських здібностей. Що стосується стилів поведінки у конфлікті, то високий та середній рівень розвиненості домінуючого стилю поведінки у конфлікті «суперництво» $(66,14 \%)$ свідчить, що ДІПС, які його використовують, не зацікавлені у співпраці з іншими людьми, здатні на вольові рішення і намагаються задовольнити власні інтереси за рахунок інтересів інших, шляхом нав'язування їм власного рішення проблеми. Для досягнення мети використовують свої вольові якості.

Високий рівень розвиненості домінуючого стилю поведінки у конфлікті «уникання» $(71,65 \%)$ проявляється через відмову ДІПС від співпраці з відстоювання своїх прав та інтересів і полягає в ухиленні від визнання та вирішення конфлікту. Високий рівень розвиненості домінуючого стилю поведінки у конфлікті «пристосування» (78,74\%) свідчить, що ДІПС співпрацює з іншою людиною і не намагається при цьому відстоювати власні інтереси. Тобто ДІПС вважає, що результат справи значно більш важливий для іншої людини, ніж для нього, що він не зможе захистити свої інтереси. Високий рівень розвиненості домінуючого стилю поведінки у конфлікті «співробітництво» $(62,20 \%)$, вказує на те, що ДІПС активно беруть участь у вирішенні конфлікту і відстоюють свої інтереси, але намагаються при цьому співпрацювати 3 іншою стороною. Цей стиль потребує більш тривалої роботи порівняно з більшістю інших підходів до конфлікту, оскільки передбачає спочатку з'ясування всіх потреб, турбот та 
інтересів обох сторін, а потім їх обговорення. ДІПС, які демонструють високий рівень розвиненості домінуючого стилю поведінки у конфлікті «компроміс» $(79,53 \%)$, готові дещо поступитися в своїх інтересах для того, щоб також частково задовольнити інтереси іншої сторони, яка робить те ж саме. Такі дії можуть певною мірою нагадувати співробітництво. Однак компроміс досягається на більш поверхневому рівні порівняно зі співробітництвом.

За тестом Б. Басса високий та середній рівень спрямованості ДІПС на справу діагностовано у 81,10\%, спрямованості на себе - у $78,74 \%$, а спрямованості на спілкування - у $71,65 \%$ опитаних. Якщо результати спрямованості ДІПС на справу мають позитивний характер, то значна кількість ДІПС які під час взаємодії демонструють спрямованість на себе свідчить про наявність певних проблем. Такі ДІПС орієнтуються на отримання прямої винагороди за свої дії безвідносно до змісту і якості виконаної роботи, при цьому під час взаємодії переважно обирають суперництво, найбільш неконструктивний спосіб розв'язання проблем.

Поведінковий компонент складових компетентності у спілкуванні досліджувався за допомогою опитувальника 3 визначення рівня сформованості комунікативних, перцептивних та інтерактивних умінь і навичок професійного спілкування. Як свідчать результати дослідження, найбільш розвинені у ДІПС комунікативні вміння - 87,40\% опитаних по- казали високий та середній рівень, на другому місці інтерактивні вміння - 79,53\%, на третьому - перцептивні вміння 3 результатом $73,23 \%$. Водночас, найбільша кількість опитаних - 26,77\%, - показали низький рівень розвиненості саме перцептивних вмінь. Порівняно 3 показниками когнітивного компоненту, показники поведінкового компоненту дещо вищі. Скоріше за все, головною причиною цього є те, що результати опитування не захищенні від певних викривлень пов'язаних з бажанням піддослідних давати соціально бажані відповіді.

Для визначення загального рівня розвиненості компонентів та складових компетентності ДІПС у професійному спілкуванні було розраховано інтегративний показник за методикою В. А. Семиченко. Розрахунки засвідчили, що найбільш розвинені у ДІПС поведінковий компонент інтерактивної компетентності - 2,06 бала та поведінковий компонент комунікативної компетентності - 2,00 бала. Найменш розвиненими виявилися когнітивний компонент перцептивної компетентності - 1,45 бала та когнітивний компонент інтерактивної компетентності - 1,69 бала. В цілому рівень розвиненості усіх складових компетентності ДІПС у професійному спілкуванні перебуває на рівні нижче середнього $(<2)$ і потребує подальшого розвитку.

\section{Висновки та перспективи подаль-}

ших розвідок. Рівень компетентності ДІПС у професійному спілкуванні визначає рівень 
його професійної компетентності і впливає на ефективність професійної діяльності. Збагачення досвіду спілкування сприяє усвідомленню ДІПС того, що компетентне професійне спілкування $є$ однією з головних складових професійної майстерності, мотивує його до здобуття та вдосконалення знань, вмінь, навичок та особистісних якостей i, як наслідок, надає можливість більш ефективно виконувати службові завдання. В результаті емпіричного дослідження встановлено, що складові компетентності ДІПС у професійному спілкуванні перебувають на рівні розвиненості нижче за середній і потребують подальшого розвитку. Досить високі показники особистісного компоненту усіх складових компетентності ДІПС дозволяють стверджувати, що у ДІПС наявний суттєвий особистісний потенціал, який необхідно врахувати при розробці засобів підвищення рівня компетентності ДІПС, що становить важливий перспективний напрям подальших досліджень.

\section{Перелік використаних джерел:}

1. Луц̧ький О. Л. Професійне спілкування як складова готовності майбутніх офіцерів-прикордонників до роботи в міжнародних пунктах пропуску через державний кордон [Електронний ресурс] / О. Л. Луцький // Збірник наукових праць Хмельницького інституту соціальних технологій Університету "Україна". - 2011. - № 4. - С. 105-109. - Режим доступу: http://nbuv.gov.ua/UJRN/ Znpkhist_2011_4_24

2. Назаренко B. О. Психологічні умови розвитку комунікативної компетентності керівників Державної прико- рдонної служби України: Автореф. дис... канд. психол. наук: 19.00.09 / В.О. Назаренко ; Нац. акад. Держ. прикордон. служби України ім. Б.Хмельницького. - Хмельниц., 2007. - 19 с.

3. Балищьький I. I. Методичні рекомендації науковопедагогічному складу щодо формування культури професійного спілкування у майбутніх офіцерівприкордонників [Електронний ресурс] / I. I. Балицький // Збірник наукових праць Національної академії Державної прикордонної служби України. Сер. : Педагогічні та психологічні науки. - 2013. - № 3. - С. 17-25. Режим доступу: http://nbuv.gov.ua/UJRN/ znpnapv_ppn_2013_3_4

4. Берестецькка Н. В. Особливості підготовки майбутніх офіцерів-прикордонників до професійного спілкування [Електронний ресурс] / Н. В. Берестецька, Т. Л. Щеголєва // Збірник наукових праць Національної академії Державної прикордонної служби України. Серія : Педагогічні та психологічні науки. - 2013. - № 2. - С. 17-23. Режим доступу: http://nbuv.gov.ua/UJRN/ znpnapv_ppn_2013_2_4

5. Шумовецьька С. П. Підготовка курсантів до професійного спілкування та досвід вивчення вимог Відомчих стандартів культури прикордонної служби при викладанні навчальної дисципліни «Українська мова за професійним спрямуванням» [Електронний ресурс] / С. П. Шумовецька, I. В. Сніцар. // Вісник Національної академії Державної прикордонної служби України. - 2013.

- Вип. 4. - Режим доступу: http://nbuv.gov.ua/UJRN/ Vnadps_2013_4_17

6. Карпов А. В. Рефлексивность как психическое свойство и методика ее диагностики // Психологический журнал.- 2003.- Т. 24.- № 5.- С. 45-57.

\section{References (Transliteration):}

1. Lutskiy O. L. Profesiyne spilkuvannya yak skladova gotovnosti maybutnih ofItseriv-prikordonnikiv do roboti $\mathrm{v}$ mizhnarodnih punktah propusku cherez derzhavniy kordon 
[Elektronniy resurs] / O. L. Lutskiy // Zbirnik naukovih prats Hmelnitskogo Institutu sotsialnih tehnologiy Universitetu "Ukrayina". - 2011. - \# 4. - S. 105-109. Rezhim dostupu: http://nbuv.gov.ua/UJRN/ Znpkhist_2011_4_24.

2. Nazarenko $\quad$ V. O. Psihologichni umovi rozvitku komunikativnoyi kompetentnosti kerivnikiv Derzhavnoyi prikordonnoyi sluzhbi Ukrayini: Avtoref. dis... kand. psihol. nauk: 19.00.09 / V.O. Nazarenko ; Nats. akad. Derzh. prikordon. sluzhbi Ukrayini Im. B.Hmelnitskogo. Hmelnits., 2007. - 19 s.

3. Balitskiy I. I. Metodichny rekomendatsiyi naukovopedagogIchnomu skladu schodo formuvannya kulturi profesIynogo spilkuvannya u maybutnih ofItserivprikordonnikiv [Elektronniy resurs] / I. I. Balitskiy // Zbirnik naukovih prats Natsionalnoyi akademiyi Derzhavnoyi prikordonnoyi sluzhbi Ukrayini. Ser. : Pedagogichni ta psihologichni nauki. - 2013. - \# 3. - S. 1725. - Rezhim dostupu: http://nbuv.gov.ua/UJRN/ znpnapv_ppn_2013_3_4.

4. Berestetska N. V. Osoblivosti pidgotovki maybutnih ofItseriv-prikordonnikiv do profesiynogo spilkuvannya [Elektronniy resurs] / N. V. Berestetska, T. L. Schegoleva // Zbirnik naukovih prats Natsionalnoyi akademiyi Derzhavnoyi prikordonnoyi sluzhbi Ukrayini. Seriya : PedagogIchnI ta psihologichni nauki. - 2013. - \# 2. - S. 17-23. - Rezhim dostupu: http://nbuv.gov.ua/UJRN/ znpnapv_ppn_2013_2_4

5. Shumovetska S. P. Pidgotovka kursantiv do profesiynogo spilkuvannya ta dosvid vivchennya vimog Vidomchih standartiv kulturi prikordonnoyi sluzhbi pri vikladanni navchalnoyi distsiplini «Ukrayinska mova za profesiynim spryamuvannyam» [Elektronniy resurs] / S. P. Shumovetska, I. V. Snitsar. // Visnik Natsionalnoyi akademiyi Derzhavnoyi prikordonnoyi sluzhbi Ukrayini. 2013. - Vip. 4. - Rezhim dostupu: http://nbuv.gov.ua/ UJRN/Vnadps_2013_4_17

6. Karpov A. V. Refleksivnost kak psihicheskoe svoystvo i metodika ee diagnostiki // Psihologicheskiy zhurnal.- 2003. - T. 24.- \# 5.- S. 45-57.

\section{Presniakova Liudmyla}

Senior officer of information assessment unit at the Administration of the State Border Guard Service of Ukraine, Kyiv (Ukraine)

\section{RESULTS OF EMPIRICAL RESEARCH OF BORDER GUARD INSPECTOR'S COMPETENCE IN PROFESSIONAL COMMUNICATION}

\section{ABSTRACT}

The results of empirical research of border guard inspector's competence in professional communication have been presented in the article. The concept of «competence in professional communication» has been determined; its structure has been defined. Cognitive, personal and behavioral components of communicative, perceptual and interactive competence components of border guard inspectors in professional communication have been diagnosed.

Diagnosis of cognitive component showed that border inspectors are good at general characteristics of professional communication, but they do not have deep knowledge in psychological features of the perceptual component of professional communication. It has been proved that the personal component of communicative competence of border guard inspectors is characterized by a high level of negative communication systems formation, low general communicative tolerance and high level of aggression and hostility in communication; their perceptual competence has undeveloped empathy ability formation; low level of reflexivity, focus on acceptance, understanding the partner and reaching 
a compromise in the interaction. The interactive competence is characterized by underdevelopment of border guard inspector's leadership skills, dominance of conformation and avoidance styles in conflict situations, focus on professional communication on themselves. Diagnosis of the behavioural component showed that border guard inspectors have better developed communication skills, but perceptual skills are worse. It has been concluded that all competence components of border guard inspectors in professional communication are formed at the level lower than a middle one and they need further development.

Key words: professional communication, knowledge, skills, personal qualities, competence in communication, communicative competence, perceptive competence, interactive competence.

\section{Преснякова Людмила}

Стариий офицер отдела оценки информации информаџионно-аналитического управления Администраџии Государственной пограничной службы Украины, г. Киев (Украина)

\section{РЕЗУЛЬТАТЫ ЭМПИРИЧЕСКОГО ИССЛЕДОВАНИЯ КОМПЕТЕНТНОСТИ УЧАСТКОВОГО ИНСПЕКТОРА ПОГРАНИЧНОЙ СЛУЖБЫ В ПРОФЕССИОНАЛЬНОМ ОБЩЕНИИ}

Аннотация. В статье приведены результаты эмпирического исследования компетентности участковых инспекторов пограничной службы в профессиональном общении. Уточнено понятие «компетентность в профессиональном общении» и ее структура. Установлено, что инспекторы имеют недостаточный уровень знаний (когнитивный компонент) и навыков (поведенческий компонент) профессионального общения, неразвитые профессионально важные личностные качества (личностный компонент), что негативно влияет на эффективность их профессиональной деятельности. Выявлены высокий уровень негативных коммуникативных установок, агрессивности и враждебности в общении, неразвитая коммуникативная толерантность, эмпатичность и рефлексивность, неконструктивные стратегии поведения в конфликте. Сделан вывод, что все компоненты компетентности участковых инспекторов пограничной службы в профессиональном общении сформированы на уровне ниже среднего и требуют дальнейшего развития.

Ключевые слова: профессиональное общение, знания, умения, навыки, личностные качества, компетентность в общении, коммуникативная компетентность, перцептивная компетентность, интерактивная компетентность. 